\title{
Textual Fantasies and Culturality in Native American Fiction: A Review Article of New Books by Treuer and Justice
}

\author{
Angeline O'Neill \\ University of Notre Dame Australia
}

Follow this and additional works at: https://docs.lib.purdue.edu/clcweb

(3)

Part of the Comparative Literature Commons, and the Critical and Cultural Studies Commons

Dedicated to the dissemination of scholarly and professional information, Purdue University Press selects, develops, and distributes quality resources in several key subject areas for which its parent university is famous, including business, technology, health, veterinary medicine, and other selected disciplines in the humanities and sciences.

CLCWeb: Comparative Literature and Culture, the peer-reviewed, full-text, and open-access learned journal in the humanities and social sciences, publishes new scholarship following tenets of the discipline of comparative literature and the field of cultural studies designated as "comparative cultural studies." Publications in the journal are indexed in the Annual Bibliography of English Language and Literature (Chadwyck-Healey), the Arts and Humanities Citation Index (Thomson Reuters ISI), the Humanities Index (Wilson), Humanities International Complete (EBSCO), the International Bibliography of the Modern Language Association of America, and Scopus (Elsevier). The journal is affiliated with the Purdue University Press monograph series of Books in Comparative Cultural Studies. Contact: <clcweb@purdue.edu>

\section{Recommended Citation}

O'Neill, Angeline. "Textual Fantasies and Culturality in Native American Fiction: A Review Article of New Books by Treuer and Justice." CLCWeb: Comparative Literature and Culture 13.2 (2011): <https://doi.org/10.7771/ 1481-4374.1748>

This text has been double-blind peer reviewed by $2+1$ experts in the field.

The above text, published by Purdue University Press @Purdue University, has been downloaded 934 times as of $11 /$ $07 / 19$.

This document has been made available through Purdue e-Pubs, a service of the Purdue University Libraries. Please contact epubs@purdue.edu for additional information.

This is an Open Access journal. This means that it uses a funding model that does not charge readers or their institutions for access. Readers may freely read, download, copy, distribute, print, search, or link to the full texts of articles. This journal is covered under the CC BY-NC-ND license. 


\section{PURDUE}

UNIVERSITY PRESS <http://www.thepress.purdue.edu>

\section{CLCWeb: Comparative Literature and Culture}

ISSN 1481-4374 <http://docs.lib.purdue.edu/clcweb> Purdue University Press (c) Purdue University

CLCWeb: Comparative Literature and Culture, the peer-reviewed, full-text, and open-access learned journal in the humanities and social sciences, publishes new scholarship following tenets of the discipline of comparative literature and the field of cultural studies designated as "comparative cultural studies." In addition to the publication of articles, the journal publishes review articles of scholarly books and publishes research material in its Library Series. Publications in the journal are indexed in the Annual Bibliography of English Language and Literature (Chadwyck-Healey), the Arts and Humanities Citation Index (Thomson Reuters ISI), the Humanities Index (Wilson), Humanities International Complete (EBSCO), the International Bibliography of the Modern Langua-ge Association of America, and Scopus (Elsevier). The journal is affiliated with the Purdue University Press monog-raph series of Books in Comparative Cultural Studies. Contact: <clcweb@purdue.edu>

Volume 13 Issue 2 (June 2011) Book Review Article Angeline O'Neill, "Textual Fantasies and Culturality in Native American Fiction:

A Review Article of New Books by Treuer and Justice" <http://docs.lib.purdue.edu/clcweb/vol13/iss2/10>

Contents of CLCWeb: Comparative Literature and Culture 13.2 (2011)

Thematic issue About Indigenous Literatures

Ed. Angeline O'Neill and Albert Braz

<http://docs.lib.purdue.edu/clcweb/vol13/iss2/> 


\section{Angeline O'NEILL}

\section{Textual Fantasies and Culturality in Native American Fiction:} A Review Article of New Books by Treuer and Justice

The relationship between Western scholarship and Indigenous storytelling, whether oral or written, has been and continues to be problematic. As many scholars have noted in recent years, critical theory often adds to the confusion, promoting a fraught relationship between teller, text, and reader. Not surprisingly, it has prompted outcries from Indigenous and non-Indigenous writers, readers, and scholars alike. This is why Ojibwe novelist and scholar David Treuer's Native American Fiction: A User's Manual and Cherokee novelist and critic Daniel Heath Justice's Our Fire Survives the Storm: A Cherokee Literary History make a fascinating and important study. Readers are presented with two different notions of "Native literature," each informed by a contrasting idea of what literary scholarship is and should be. Consequently, the relevance of conversive scholarly strategies, according to which literary scholarship is a form of intersubjective and transformative communication, is foregrounded.

Treuer's book is a curious and thought-provoking text. The title is most apt, as, after questioning the very existence of Native American fiction, he claims to concern himself with the many ways in which the idea of the Native novel has been and is "used" by writers, readers, and critics. At its centre, however, is Treuer's own analysis of works by Louise Erdrich (Ojibwe), Sherman Alexie (Spokane/Coeur d'Alene), and Leslie Silko (Laguna), among others. It is an analysis issuing from the heart of Western literary history and critical theory through which Treuer argues that the "true value" of a text is ascertained by focusing on the word and ignoring the identity and constructed authority of the author (3). As such, the positionality of author and reader alike is dismissed, and it would seem that both are silenced simultaneously and spoken for by Treuer himself in his capacity, ironically, as reader and author. This contrasts with Justice's approach where he aims to show the relationship between an old and proud Cherokee literary tradition and processes of cultural regeneration and recovery. Justice argues that literary tradition is a powerful form of continuity and that every addition to this tradition is a form of cultural renewal, whether it is oral or written. In this way, the texts of Treuer and Justice constitute a thoughtprovoking dialogue on the nature of Indigenous literature and scholarship.

In Native American Fiction: A User's Manual Treuer seeks to champion Western literary history and theory, but evidences unintentionally their limitations instead. Interestingly, early in the text he argues that "to read and engage and love and consume and consummate a relationship with a story is to believe. And belief is a critical, if sometimes unconscious, habit we practice. How we practice it, what we are accustomed to believing in literature, and what we cannot accept are matters of training" (8). Treuer's training in and familiarity with Western literature are certainly impressive as, among others, he draws on the works of Aristotle, John Milton, Alexander Pope, Nathaniel Hawthorne, Ernest Hemingway, and Thomas Mann, as well as Charles Baudelaire, Eric Auerbach, Stéphane Mallarmé, Homer, François-René de Chateaubriand, Marcel Proust, and Dante Alighieri. Treuer employs these writers in an attempt to examine "how novels act" (5) and to support his belief that "the sentiment (and it is a sentiment) that Native American literature should be defined by the ethnicity of its producers (more so than defined by anything else) says more about politics and identity than it does about literature ... Ultimately, the study of $\mathrm{Na-}$ tive American fiction should be the study of style" (4). Early in this collection of essays, he acknowledges that it might be seen as a "dangerous turning back of the clock, or the rapid undoing of three decades of hard work by critics and authors" (4). Nevertheless, he maintains that issues such as ethnicity, politics, and identity prevent readers from a proper appreciation of the literariness of a text: "It is important to remember that we are entering textual fantasies here, not a sweat lodge. That is, despite what the books might mean to us, as individuals or Indians, the books function as books. By making sweeping claims about the culturality of a text or the intentionality of the writer, we might save the book, but we will destroy the literature" (6). Unfortunately, he engages in many sweeping claims of his own.

Native American literature, Treuer claims, has been damaged by the way we are taught to interpret it "with our hearts, not with our heads" (163) and, as such, "the literary work in Native American literature takes a backseat to issues of identity and perceived 'authenticity'" (163). This is, I believe, the greatest weakness in his argument: the value of literature must be determined solely by a close critical reading, otherwise one's judgment is clouded by knowledge of the circumstances of textual production and authorial intention. In other words, cultural and political awareness is detrimental to the perceived literary value of a text. Not surprisingly, as suggested by the title of his final essay, "Some Final Thoughts about the Non-Existence of Native American 
Angeline O'Neill, "Textual Fantasies and Culturality in Native American Fiction:

A Review Article of New Books by Treuer and Justice"

page 3 of 6

CLCWeb: Comparative Literature and Culture 13.2 (2011):

<http://docs.lib.purdue.edu/clcweb/vol13/iss2/10>

Thematic Issue About Indigenous Literature. Ed. Angeline O'Neill and Albert Braz

Fiction," he works towards the conclusion that "if Native American literature is worth thinking about at all, it is worth thinking about as literature" (195). But this, he contends, does not happen, as we have been taught to read it as Native American rather than as literature. Consequently, Native American fiction does not exist (195). In the midst of what appears to be Eurocentric and academic snobbery, Treuer's reader is left wondering how this claim will be substantiated. He provides an interesting scenario - as an insider to both worlds - and he chooses to use one (Western literature and scholarship) to deny the existence of the other (Native literature). It would, however, be too easy to dismiss Native American Fiction summarily. Treuer asks some pertinent questions and makes some informed observations, including the manner in which many readers' interpretations are the product of popular misconceptions and images. That said, he neglects to mention that preconceptions can function in any interpretation, not only Native literature, and can effectively be dealt with through contextualization rather than by avoiding context. What is literature and what is a novel, Treuer asks? How important are issues of language, myth, culture, belief, and authenticity? Novels, he claims, are wishes, fantasies, fairy tales and do not represent reality, although they can create their own realities (201). In this context, he is distinctly ill at ease with the notion of a Native American novel, maintaining that it does not come into existence "simply or only because an Indian wrote it, or because someone who is Indian asserts that the product of his/her imagination (always a messy thing) is fundamentally and essentially Indian" (3). Paradoxically, he insists that his essays are concerned with interpretation, with "how novels act, not with how authors or critics would like them to or what we think the author's intention was" (5).

To be fair, Treuer does dispense some glowing praise on Erdrich and on Silko. He is interested in the process of interpretation, and it becomes clear that one of his aims in this collection is to provide textual evaluation based on a close reading of his chosen novels within the context of Western literary history. The problem is that he fails to acknowledge the limitations of his own interpretation and, relying heavily on some Western literary classics, too readily adopts an authoritative and cynical approach to alternate readings. In the essay "The Myth of Myth" he takes his thesis one step further. While he acknowledges that no novel has had a more profound impact on Native American literature than Ceremony, which meets all the criteria of a Native American novel, he then seeks to show that these criteria are in fact not Native American at all. Once again, readers are presented with the either/or scenario. He appears to argue that no mutual influence is allowable and that once Native literature adopts or manipulates so-called Western techniques, it is somehow less authentic, somehow tainted. However, no literatures develop in isolation and this is not necessarily a bad thing. Treuer ignores the fact that, particularly in today's global village, some element of literary cross-pollination is unavoidable. This affects not only the process of writing but also of reading. In his discussion of Silko's use of symbolism and simile, for example, he asserts that "the very appropriateness of [Silko's ] images ... renders them unable to lift the novel out of a realist or physicalist mode of representation, and the images smack more clearly of the early Romantics than they do of the Symbolists" (129). The link between Tayo's emotions and the landscape, he states, can be traced back to the early eighteenth century. Chateaubriand's Atala is given as an example (129). Further on he argues that the use of myth, such as we find in Ceremony, has helped construct a "tribal naivete that has been the stock and trade of literary representations of Indian myths from the eighteenth century onward" (135). In other words, he argues that myth is itself a myth and by virtue of the different ways myth and prose function in her text, Silko is guilty of propagating this sense of tribal naiveté. The points at which the narrative changes direction only appear "nativistically ritualistic" (136). In reality, we are told, they have "therapeutic and literary ancestors, not Indian ancestors" (136). According to Treuer, myth in Ceremony functions as cultural nostalgia. He is so keen to drive this point home that he even claims that Tayo's struggles are more similar to those faced by Jesus in the desert than to Pueblo myth (142) and that Tayo's moral and sociopolitical predicaments are in fact those of Luke Skywalker in Star Wars, which appeared in cinemas in 1977 (the year Ceremony was published). He concludes that "both stories are products of their time and the stories that surround them" (144). Needless to say, this contradicts his continual dismissal of context.

At this point, I am reminded of Susan Berry Brill de Ramirez's discussion of conversivity and Native American literature, where scholars are listener-readers of literary texts before becoming storyteller-guides, assisting others to become listener-readers (1). In this way literary scholarship becomes a transformative act of communication. Oral storytelling, Brill de Ramirez suggests, is central to all literatures, not only Native literatures. In contrast, she says, literary criticism has evolved into a largely textual activity; a mismatch between readings and theoretical frameworks. While her somewhat blithe dismissal of critical theory should be challenged, her emphasis on context and positionality is appropriate. So too, her concern that scholars become more appreciative 
Angeline O'Neill, "Textual Fantasies and Culturality in Native American Fiction:

A Review Article of New Books by Treuer and Justice"

page 4 of 6

CLCWeb: Comparative Literature and Culture 13.2 (2011):

<http://docs.lib.purdue.edu/clcweb/vol13/iss2/10>

Thematic Issue About Indigenous Literature. Ed. Angeline O'Neill and Albert Braz

of the oral roots of all languages and incorporate this into their critical approaches is most pertinent and calls Treuer's approach into question. As Greg Sarris (Coast Miwok/Pomo) has said, "tradition is not fixed, but an ongoing process" (qtd. in Brill de Ramirez 2). Herein we find another problem issuing from Native American Fiction: A User's Manual, for "it is one thing to celebrate powerful literary achievements and to understand how new work can build on the work of the past; it is quite another thing to endorse a theory of evolutionary progress or steady organic development that one knows is bankrupt" (Greenblatt 57). While there is no evidence to suggest that Treuer is promoting ideological bankruptcy, he comes perilously close to advocating an evolutionary theory of literary progress.

In Our Fire Survives the Storm: A Cherokee Literary History Justice has something different to say. He establishes that the text is inseparable from its origins as he reveals a Cherokee aesthetic, central to which is "an interweaving process that bends time and sequence to its own purposes and is ever-changing with each re-telling of stories" (Larson 59). Underlying every sentence in the text is the relationship between Indigenous wisdom traditions and the sacred power of words and stories. Stories can create the world or destroy it, and each person must therefore treat words carefully. Justice aims to promote the spirit of Cherokee nationhood through his people's sense of culture, history and literature, combined with kinship connections and tribal obligations (150). Peoplehood is "the communitistic worldview within which the nation's understanding of itself and its place in the cosmos is embedded," and it has four interdependent elements: language, sacred history, ceremonial cycle, and place/territory (25). Justice sees literature as a way of achieving this worldview: a powerful assertion of continuity, regardless of whether it is oral or written, interview-form or letters, novels, poems, plays, newspaper articles, treaties, historical monographs, medico-magical notebooks, songs, dances, drawings, or sermons, in Tsalagi, English or Spanish. He defines Cherokee literature as "anything that Cherokees write or speak with the intention of meaningful endurance" (14). With each addition to the Cherokee literary tradition Justice asserts that a living presence is renewed, which will be passed to following generations.

One of Justice's seminal ideas about text is that "words shape us, give us form and substance; they provide a depth of purpose that can strengthen us or a corrosive pain that eats away at our humanity or makes us destructive and violent" (206). He discusses how this happens and its effects in both traditional and contemporary contexts. As such, one of his strengths is that he writes as both a novelist and a scholar, engaging different levels of discourse and, in a practical way, challenging "the Eurowestern academy" and its prodigy "the academic": a professional who participates in the institutional structure of resources and privileges of the Eurowestern academy (207). She/he is distinct from a scholar to whom "knowledge and wisdom traditions are of substantive and purposeful concern" (207). Of course, Justice is careful to point out that he is part of the system himself and that there is not necessarily anything wrong with this as long as one remembers that such a position should be used "to serve both the pursuit of truth and the dignified decolonisation of Indigenous peoples ... The academic enterprise is ... a part of the process of intellectual and spiritual development" (208). This comment highlights one of the underlying concerns of the text, the importance and ethical dimensions of literary criticism: to ignore this is, according to Justice, "intellectually dishonest and lazy, as well as morally bankrupt" (215). Unlike Treuer, who seems to view literary criticism as a Western invention capable of disproving the existence of Native literature, Justice argues that Native literary criticism has a long genealogy. After all, he asks, what were the Indigenous law keepers of old if not partially textual interpreters? (208). Our Fire Survives the Storm is a Cherokee literary history, focusing on a diverse range of texts. Subjectivity is central to his project and Justice asserts that his methodology is borne of various Cherokee cultural expressions and understandings. He seeks to articulate a literary theory rooted in the complementary Chicamauga and Beloved methodologies (31); Chicamauga consciousness is rooted in concepts of war and resistance, whereas the Beloved Path requires "actively peaceful resistance" (156). He stresses the importance of Chickasaw historian Amanda J. Cobb's notion of continuance, or the relationship between memory and story, to an understanding of his aims (15). Intellectual sovereignty is central to this as it provides a philosophical and political foundation from which to define the terms and conditions of analysis. In response to the criticism that his is an essentialist text, Justice does not insist that tribal-centered scholarship is the only means of sensitive or insightful analysis but - contrary to Treuer - he does see an understanding of community as crucial to a nuanced reading of the text (10).

If words shape the world, then stories are never far from their contexts. Justice develops this idea through the three parts of his text: "Deep Roots," "Geographies of Removal," and "Regeneration." In part one he examines some cultural principles, historical moments, and social movements central to Cherokee nationhood. This historical and thematic analysis of the interplay between Cherokee literature and Cherokee social history is the basis of Justice's methodology. From 
this point, he explores the diverse interpretive possibilities of the literature. An understanding of peoplehood, "the dynamic and active participation in the relational reality of the tribal nation" (25), is critical. In part two, "Geographies of Removal," he discusses the physical and psychic removal of Cherokees from their lands, and the contribution that this has made to the new stories that speak to the community. Cherokee writers discussed in this section include politician and writer John Ross, playwright Lynn Riggs, novelist John Milton Oskison, actor Will Rogers, and historian Emmet Starr, all of whom are in one way or another concerned with the complementary Chicamauga and Beloved methodologies. And in part three, "Regeneration," he traces the inextricable link between the Cherokee literary tradition, cultural regeneration and recovery, and continuity. In particular, Justice focuses on contemporary Cherokee literature, employing a comparative approach to works by Marilou Awiakta and Thomas King, Wilma Mankiller and Geary Hobson, and Diane Glancy and Robert Conley. Awiakta's Selu: Seeking the Corn-Mother's Wisdom (1993) is paired with King's Truth and Bright Water (1999), and both are seen as examples of the Beloved Path principles concerned with Indian survival and reconnecting with "the web of relationships between humans and other animals, spirits of this world and those beyond, and all participants in creation" (158). In addition, both texts deal with pan-Indian issues and with realigning gender. However, Mankiller's autobiography, Mankiller: A Chief and Her People (1993) is considered alongside Hobson's The Last of the Ofos (2000), since they embrace the Chickamauga consciousness of defiance. Mankiller is not concerned with the individual but with "tribal relationships of interdependence and mutual definition" (182). Perhaps not surprisingly, Conley's Mountain Windsong (1992) is then compared with Glancy's Pushing the Bear (1996) and both are found to support the Chickamauga consciousness and Beloved Path readings. While Conley is concerned with Cherokee ceremonial traditions and nationhood in the face of severe U.S. oppression, Clancy explores the insecurities of being a Christian mixed-blooded woman caught between the legacies of her diverse cultures, faiths, and histories (196). In this way, Justice examines texts that clearly express the principles of nationhood, and in the process draws attention to some compelling writers. He aims to show his readership that "today, as yesterday and tomorrow, our fire survives the storm" (220).

In his "Afterword" Justice emphasizes the role of scholars and scholarship in achieving nationhood. It is, however, a different understanding of these concepts than what we find in Native American Fiction: A User's Manual. While Treuer appears to embrace the tradition of Western scholarship as still evidenced in many institutions, Justice displaces the institutional structure of resources and privileges of the Eurowestern academy and the Whiteness that goes with it. NonNative scholars and scholars, in particular, become the Other as he addresses primarily Native scholars. He explains: "Our literature is both a product and an extension of our nationhood; to assert oneself as a Cherokee is to locate oneself in relationship to all these complex and multidimensional discourses - stories - of community" (209). To deny or ignore such voices in favor of non-Natives who have "assumed authority" is to promote colonialism. In this way Justice maintains that critical theory contains an important ethical dimension. He is, I believe, right to emphasize this ethical dimension. He should, however, also apply it to his own analysis. When he refers to non-Natives who challenge his belief in tribal-specific criticism, he seems to stereotype them as adhering to the ideologies of colonialism and upholding the "Eurowestern assimilationist directive from within" (209). Within whom or within what? The implication appears to be that non-Native critics are collectively driven by some sort of racist intent. As such, while Justice and Treuer are in many ways ideologically removed from each other, moments of extremism bring them closer together.

Justice does, however, acknowledge that these strong sentiments have aroused disagreement, with such scholars as Elvira Pulitano, Louis Owens, and Arnold Krupat describing work by tribal nationalists as "naïve or parochial at best and racist at worst" (211). However, Pulitano is accused of "trumpet[ing] cultural and racial hybridity" and thus "miss[ing] the point that nationcentred writers and scholars are making" when they insist on the "ethical repositioning of Indian voices" (212). Once again Justice should take care not to generalize when he accuses advocates of hybridity of "ignoring or minimizing the historical, political and cultural importance of nationhood" (211). In this context, a conversive scholarship that is relational rather than critically divisive is useful. This type of scholarship, which is based on the scholar as listener-reader, draws on the transformative power of oral and written language, both of which can be "conversive, cocreative, relational, and inter-subjective" (Brill de Ramirez 205). Yet neither Treuer nor Justice advocates such an approach directly, although both are clearly concerned by the relationship between academia and Native literature. Treuer directs his text to a primarily non-Native readership and Justice seeks a Native readership. In vastly different ways, both writers acknowledge the power of language and draw our attention to its relationship with the positionality of speak- 
Angeline O'Neill, "Textual Fantasies and Culturality in Native American Fiction:

A Review Article of New Books by Treuer and Justice"

CLCWeb: Comparative Literature and Culture 13.2 (2011):

<http://docs.lib.purdue.edu/clcweb/vol13/iss2/10>

Thematic Issue About Indigenous Literature. Ed. Angeline O'Neill and Albert Braz

er/writer and listener/reader; Justice vigorously affirms this relationship and Treuer denies it with equal vigor. While Justice advocates that culture is a performance taking place simultaneously in the past and present and giving birth to literature, Treuer determines literary value strictly according to a close textual reading that places the given text in relation to canonical Western literature. Both Native American Fiction: A User's Manual and Our Fire Survives the Storm are fascinating texts, each with inherent strengths and weaknesses. Yet it is when they are viewed alongside each other that they make particularly interesting reading, highlighting some of the many issues with which Native and non-Native scholars are confronted.

\section{Works Cited}

Brill de Ramirez, Susan. Contemporary American Indian Literatures and the Oral Tradition. Tucson: U of Arizona P, 1999.

Eigenbrod, Renate. Travelling Knowledges: Positioning the Im/Migrant Reader of Aboriginal Literatures in Canada. Winnipeg: U of Manitoba P, 2005.

Greenblatt, Stephen. "Racial Memory and Literary History." Globalizing Literary Studies. Ed. Carlos J. Alonso. Special issue PMLA: Publications of the Modern Language Association of America 116.1 (2001): 48-63.

Justice, Daniel Heath. Our Fire Survives The Storm: A Cherokee Literary History. Minneapolis: U of Minnesota $P, 2006$.

Larson, Sidner. "Native American Aesthetics: An Attitude of Relationship." Melus: The Society for the Study of the Multi-ethnic Literature of the United States 17.3 (1991-1992): 53-67.

Silko, Leslie Marmon. Ceremony. 1977. New York: Penguin, 1986.

Silko, Leslie Marmon. "Language and Literature From a Pueblo Indian Perspective." Yellow Woman and a Beauty of the Spirit: Essays On Native American Life Today. New York: Simon and Schuster, 1997. 6072.

Treuer, David. Native American Fiction: A User's Manual. Minneapolis: Graywolf, 2006.

Wilson, James. The Earth Shall Weep: A History of Native America. New York: Grove, 1999.

Reviewer's profile: Angeline O'Neill teaches English literature at The University of Notre Dame Australia. Her interests in research include comparative Indigenous literatures, children's literature, Australian literature, and literary theory. O'Neill's recent publications include "Creating a New Space: From Literary Migrants to Resistance Writers," Comparing Migration: The Literatures of Canada and Québec (Ed. Catherine Khordoc and Marie Carrière, 2008) and "Anthologizing Indigenous Literature," On Anthologies: The Politics and Pedagogy of Anthologizing (Ed. Jefrrey Di Leo), Special Issue symploke: A Journal for the Intermingling of Literary, Cultural and Theoretical scholarship (2004), and she has co-edited, with Anne Brewster and Rosemary Van den Berg, Those Who Remain Will Always Remember: An Anthology of Aboriginal Writing (2000). Email: <angeline.oneill@nd.edu.au> 